\title{
Tele-Analytical Characterization of the Eburnean Tectonic Structures within the Birimian Formations of Mako Area, Eastern Senegal
}

\author{
Ibrahima Gassama ${ }^{1}$, Moussa Dabo ${ }^{1,2^{*}}$, Emmanuel Tama Samoura1, Mamadou Ndiaye ${ }^{1}$ \\ ${ }^{1}$ Department of Geology, School of Science and Technology, Sheikh Anta Diop University, Dakar, Senegal \\ ${ }^{2}$ Géosciences Rennes, UMR 6118, CNRS, Université de Rennes 1, Campus de Beaulieu, Rennes, France \\ Email: *moussadabo@hotmail.com
}

How to cite this paper: Gassama, I., Dabo, M., Samoura, E.T. and Ndiaye, M. (2022) Tele-Analytical Characterization of the Eburnean Tectonic Structures within the Birimian Formations of Mako Area, Eastern Senegal. International Journal of Geosciences, 13, 12-32.

https://doi.org/10.4236/ijg.2022.131002

Received: November 12, 2021

Accepted: January 8, 2022

Published: January 11, 2022

Copyright $\odot 2022$ by author(s) and Scientific Research Publishing Inc. This work is licensed under the Creative Commons Attribution International License (CC BY 4.0).

http://creativecommons.org/licenses/by/4.0/

(c) (i) Open Access

\begin{abstract}
The tectonic structures of the Mako area in the Kédougou-Kéniéba inlier (KKI) were mapped with tele-analytical investigation which is validated by field data. This study is based on different images processing in particular: 1) the colored combinations ( 1 to 5 ) and panchromatic (8) thematic mapping bands of the Landsat- $8\left(\mathrm{ETM}^{+}\right)$satellite; 2$)$ Digital Elevation Model (DEM) image of Space Shuttle Radar Topography Mission (SRTM); 3) airborne geophysics (aeromagnetic and radiometric) images. In these images, four major directions of lineaments NS, NNE-SSW, NW-SE and EW would be related to the tectonic structures, have been identified and mapped. Field data confirm these four structural directions and show that most of these lineaments are related to faults, shear and/or thrust zones, or even basic rock dykes. N-S to NE-SW oriented lineaments are more frequent followed by those NW-SE oriented. These two directions of lineaments are generally in correlation with trajectories of major sinistral shear zones in the Mako area. They would be associated with the $S_{2 \mathrm{a}}$ and $S_{2 \mathrm{~b}}$ schistosities relative to the $\mathrm{D}_{2}$ Eburnean major deformation. They often intersect the E-W oriented lineaments which are less frequent and sometimes folded and crenulated. This E-W oriented lineament would be prior and are associated with the $S_{1}$ schistosity of the $D_{1}$ Eburnean thrust phase of deformation. At the scale of the studied area, these major linear structures (shear zones) are conjugated and create a partitioning of deformation through an anastomosed network of mylonitic shear zones which surround weakly deformed rock bodies. All these structures would be related to the Eburnean or post-Eburnean orogenic events in this Mako area.
\end{abstract}




\section{Keywords}

Eburnean, Kédougou, Tele-Analytic, Landsat-8 Images, Tectonic, Lineament

\section{Introduction}

In the Kédougou-Kéniéba Inlier (KKI), the major tectonic structures that affect the Paleoproterozoic (Birimian) formations are essentially related to the Eburnean orogeny ([1] [2] [3] [4]). They are characterized by major shear zones, faults, folds, fractures related to Eburnean and even post-Eburnean tectono-magmatic events. Processing of satellite and airborne geophysical images provides a panoramic view of the distribution of surface and subsurface tectonic structures across the Mako area. Indeed, some tectonic structures can be highlighted in the form of lineaments resulting from the processing of appropriate images. A lineament is a simple or compound linear line, detected at the surface, the different parts of which, aligned along a straight or a curve line, stand out distinctly from their surroundings and possibly reflect a phenomenon generated below the surface ([5]).

Lineaments are linked to structural elements such as faults, fractures, fold axes and lithological contacts ([6] [7]). Many studies have shown that remote sensing, due to the synoptic nature of satellite images, has revealed the abundance of linear structures and significantly improved knowledge of the location of areas with mining potential ([8] [9]). Because of the problems associated with the sometimes sporadic distribution of rock outcrops, vegetation cover and surface weathering of outcrops, the lineaments of satellite images will be combined with those resulting from the processing of aeromagnetic geophysical images. Indeed, these lineaments of aeromagnetic geophysical images are also characteristic of sub-surface structures.

This study presents the results of the lineaments analysis in the Mako area, extracted by image processing methods (satellite and geophysical) and compared to field data in a Geographic Information System (GIS). The objective is to identify and characterize the tectonic structures of the Mako area in order to establish for the first time a detailed structural map of the Mako sector which takes into account the subsurface data. The methodological approach includes three main steps: 1) the localization and extraction of lineaments using image processing techniques (image enhancement using colored composition and filtering by Sobel directional filters); 2) comparative analysis of lineament directions using directional rosettes; 3 ) validation of tele-analytical results with field data in a GIS, followed by interpretation.

Using imagery (satellite and airborne geophysics) combined with field data, integrated into a Geographic Information System (GIS), is a new approach which allows us to validate or improve the existing structural geological map of the Mako area. 


\section{Geological Setting}

The Kédougou-Kéniéba (straddle the border between Senegal and Mali) and Kaye (western Mali) inliers (KKI) correspond to small cores of the Paleoproterozoic basement of the Leo Ridge (Figure 1(a)). They outcrop in the western part of the West African Craton (WAC) within the Neoproterozoic to Paleozoic sediments of the Taoudeni basin. The Paleoproterozoic (Birimian) formations of the KKI were divided into two Supergroups ([10]) or Groups ([11]): Mako in the West and Dialé-Daléma in the East, separated by a Main Transcurrence Zone, (MTZ) ([12]) (Figure 1(b)). In this paper, we will use the Supergroup term. The Mako Supergroup is a predominantly tholeitic volcanoplutonic complex, dated between $2205 \mathrm{Ma}$ and $2125 \mathrm{Ma}$ ([13] [14] [15] [16]). The Dialé-Daléma Supergroup is essentially detrital with turbiditic and carbonate metasediments, cross-cut by hypovolcanic and volcanic complex which mainly andesitic characteristic ([10] [17]). The sedimentary rocks are dated between $2096 \pm 8$ to $2165 \pm 1 \mathrm{Ma}$ ([18] [19]). The calc-alkaline volcanic and hypovolcanic complex has been dated between $2099 \pm 4 \mathrm{Ma}$ and $2072 \mathrm{Ma}$ ([18] [20]). These Birimian volcanosedimentary and volcanic assemblages constitute the host of several generations of granitoids in coalescing massifs distributed in two batholiths, Badon-Kakadian and Saraya-Boboti which are intrusive respectively in the Mako and Dialé-Daléma Supergroups ([1] [3]). [11] renames these batholiths under the name of Suites and distinguish: the Sandikounda-Soukouta Suite (2170 - $2140 \mathrm{Ma})$ which is intrusive in the Mako Group and the Saraya (2100 - $2060 \mathrm{Ma}$ ) and Boboti (2080 $2060 \mathrm{Ma})$ Suites, which are intrusive in the Dialé-Daléma Group. Post-Birimian dolerite dykes are intrusive later within $\mathrm{N} 20^{\circ}$ to $\mathrm{N} 90^{\circ}$ oriented eburnean tectonic structures ([11] [21]).

The intrusions of granitoids are essentially associated to the Eburnean orogenesis which also leads to variable metamorphism and deformations features.

The Eburnean metamorphism is generally in the epizonal facies and locally in the mesozonal facies, in particular at the contacts with granitic intrusions ([15] [22]). It is accompanied by an Eburnean deformation subdivided into two or three distinct phases at the KKI scale ([2] [4] [12] [23]). A $\mathrm{D}_{1}$ phase marked by an $\mathrm{N} 0^{\circ}$ to $\mathrm{N} 70^{\circ}$ oriented $\mathrm{S}_{1}$ schistosity associated by variable size of $\mathrm{P}_{1}$ overturned folds ([4] [24]). The style of the deformation of this phase is tangential tectonics ([2] [12] [24]) or peribatholitic gravity tectonic ([3] [11]). A sinistral $\mathrm{D}_{2}$ transpressive deformation phase, responsible of the large NE-SW and NW-SE shear zones ([2] [4] [11]). According to most of the above-mentioned authors, the main direction of shortening associated with this deformation would be between NW-SE. A $\mathrm{D}_{3}$ Eburnean deformation phase which is characterized by a transcurrent to dextral transtensive style. It's associated with an $\mathrm{N}^{\circ} 5^{\circ}$ and $\mathrm{N} 140^{\circ}$ oriented $\mathrm{S}_{3}$ schistosity and $\mathrm{Z}$-shaped $\mathrm{P}_{3}$ folds ([23]). Lineament analysis using satellite and geophysical images allows a good mapping of large tectonic structures at the scale of the Mako area. The results obtained by images processing are validated through a comparison with the field structural data. 


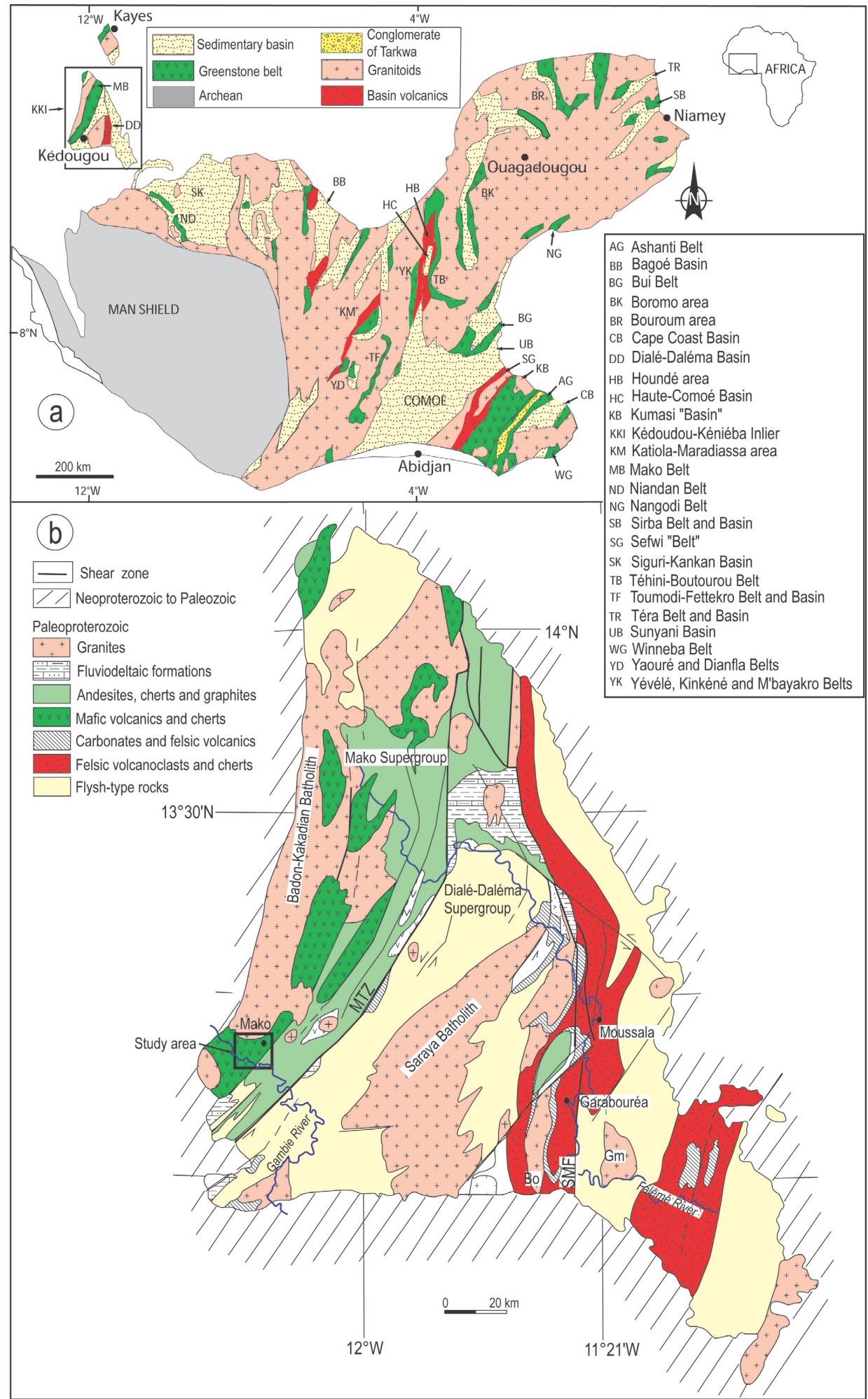

Figure 1. Kédougou-Kéniéba Inlier (KKI) in the Man shield, southern part of the West African Craton (WAC). (a) Schematic map of the major Precambrian greenstone belts of the southern part of the WAC (simplified from [24]. (b) Simplified geological map of the Birimian of KKI (modified after [24]). Rectangle delimits the study area. Bo: Boboti; Gm: Gamaye; LSZ: Lamé Shear Zone; MSZ: Mako Shear Zone; MTZ: Main Transcurrent Zone; SMF: Senegalo-Malian Fault; SSZ: Sékoto Shear Zone; RN7: National Road N7; WSZ; Wassadou Shear Zone. 
Analysis and interpretation of these data will allow a better understanding of the Eburnean and post-Eburnean deformations in the Birimian formations of Mako area in the KKI.

\section{Material and Methods}

\subsection{Material}

The material used consists of 1) Landsat-8 $\mathrm{ETM}^{+}$(Enhanced Thematic Mapper) satellite images with a resolution of $\sim 30 \mathrm{~m}$ (bands 1 to 5 ) and $15 \mathrm{~m}$ (panchromatic band 8); 2) DEM (Digital Elevation Model) with resolution of 90 m; 3) airborne geophysical images. The Landsat- 8 ETM $^{+}$image was acquired at March 14, 2020 during the dry season. In the Mako area (Sénégal), during this period, the disruptive effect of cloudiness and vegetation is minimized except for some isolated fumes due to bush fires. The characteristics of the satellite images used are mentioned in Table 1.

For the geophysical images, the data (airborne images) were collected in 2009 by the company Fugro (Fugro Airborne Surveys Corp) for the benefit of the Mines and Geology Department (DMG) of Ministry of Industry and Mines of Senegal. They were carried out within the project of "PASMI" (Support Program for the Mining Sector), which aims to consolidate Senegal's geoscience infrastructure. We obtained these geophysical data through collaboration between the "DMG" and the Geology Department of the University Cheikh Anta Diop of Dakar.

The airborne geophysical campaign acquired high resolution data, which characteristics are in Table 2.

Table 1. Characteristics of satellite images used.

\section{Landsat image $\mathrm{ETM}^{+}$Orthorectified Geo-Tiff}

acquisition date:
Path and Row:
Number of channels (bands):
spatial resolution:
Projection system:
Datum:
Spectral characteristics:

14 Mars 2020

202/051

11 bandes (B1, B2, B3, B4, B5, B6, B7, B8, B9, B10, B11)

$30 \mathrm{~m}$ (B1 à $\mathrm{B} 7$ et $\mathrm{B} 9) ; 15 \mathrm{~m}$ (B8); $100 \mathrm{~m}$ (B10, B11)

UTM (“Universal Transverse Mercator"), Zone 28N

WGS 84 ("World Geodetic System 1984")

B1 (bleu), B2 (vert), B3 (rouge), B4 (proche infrarouge), B5 (mid infrared), B6 (Shortware Infrared 1560 - $1660 \mu \mathrm{m}$ ), B7 (Shortware Infrared 2100 - $2300 \mu \mathrm{m}$ ), B8 (panchromatic), B9

(Cirrus 1360 - $1390 \mu \mathrm{m}$ ), B10 (Long wavelength infrared $1030-1130 \mu \mathrm{m}$ ), B11

(Long wavelength infrared $1150-1250 \mu \mathrm{m}$ )

\section{SRTM image Shuttle Radar Topography Mission}

Sensor bands:

Resolution:

Coverage:

Projection system:

Datum:
Band $\mathrm{C}$ et Bande $\mathrm{X}$

$90 \mathrm{~m}$

$\mathrm{N} 12^{\circ} \mathrm{W} 013^{\circ}$

UTM (“Universal Transverse Mercator"), Zone 28N WGS 84 (“World Geodetic System 1984") 
Table 2. Technical characteristics of the airborne geophysical surveys of Kédougou.

\begin{tabular}{cc}
\hline Flight line spacing & $250 \mathrm{~m}$ \\
Control line spacing & $3000 \mathrm{~m}$ \\
Flight altitude & $80 \mathrm{~m}$ \\
Flight line direction & 135 degrés \\
Control line direction & 225 degrés \\
Magnetic data logging interval & 0.05 secondes \\
Spectrometric data recording interval & 1 secondes \\
\hline
\end{tabular}

The airborne geophysical images used in this work result from the processing of geophysical data from the DMG. The software used for image processing are Geosoft Oasis Montag and Envi 4.2 for geophysical and satellite data respectively. The combination and analysis of multi-source data are carried out using ArcGis software.

\subsection{Methods}

\subsubsection{Satellite Images}

Prior to the identification and extraction of lineaments related to geological structures, the satellite images were pre-processed to minimize imagery artefacts and allow better display of geological structures. The DEM (Digital Elevation Model) type images have previously been corrected for their defects or "holes". In fact, in the raw state, some DEM images have defects which are characterized by negative gray values (Figure 2(a)). Defect correction consists of bringing the gray values back to normal between 0 and 255 pixels.

The second preprocessing corresponds to filtering and concerns the DEM and Landsat-8 $\mathrm{ETM}^{+}$(Enhanced Thematic Mapper) satellite images. Filtering is a technique aimed at removing noise from data. This noise is defined as any unnecessary data that obscures information. The noise effect is expressed by a much accentuated sawtooth appearance of a profile drawn on the unfiltered image. After filtering, the shape of the curve is smoothed, reflecting the effective elimination of the noise effect in the image (Figure 2(b)). The geometric correction aimed at bringing the image back to a planimetric reality is not necessary here. Indeed, in the GIS the images obtained are perfectly consistent with the geology map of the sector.

The computer processing of the images allows the highlighting of the lineaments. This image computer processing (directional filtering, enhancement) allows the display of lineaments relative to geological structures (fractures, faults, folds) and to the landscape (hills, streams). The choice of a lineament enhancement method must take into account its ability to enhance the high spatial frequencies associated with lineaments in all directions, even those that are not favored by the lighting source. For this purpose, directional filters have long been shown to be effective tools ([25] [26]). Among directional filters, the Sobel filter offers the possibility of enhancing lineaments in directions other than those of 

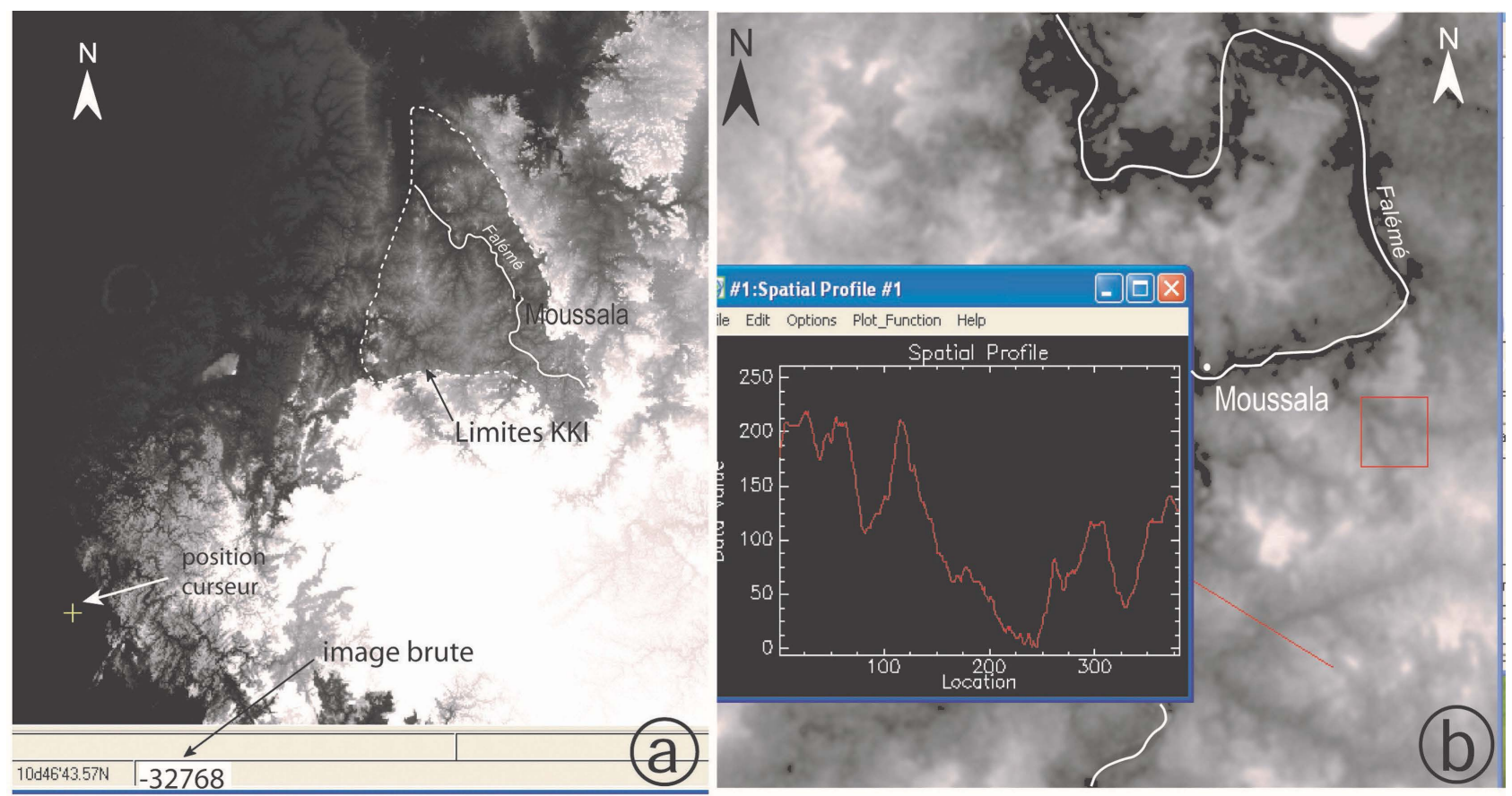

Figure 2. (a) Gray values at the cursor position (yellow cross) in MNT rough image of study area. The negative gray value $(-32,768)$ of the rough image is related to defects (gaps) that have been corrected in the following (b) image, which shows moderate indentations of profile curve. The profile location is indicated by the oblique red line that appears on the image.

the preferential enhancement by introducing directional attributes in the filtering process ([27] [28]). For Landsat-8 $\left(\mathrm{ETM}^{+}\right)$images, we used the panchromatic band (8) which has a better resolution $(15 \mathrm{~m})$ for the visualization and extraction of lineaments (Figure 3(a)). The $7 \times 7$ matrices of these Sobel filters are indicated in Table 3.

The DEM (Digital Elevation Model) images processing consists of directional shading. Shading is performed on previously corrected and filtered DEM image which is without "holes" and "noise effects". It consists to image lighting following different azimuths (four), which allow to evidence the large tectonic structures of the area (fractures, folds, faults, shear zones). These are more or less visible depending on the inclination angle of the image relative to the light source (Figure 3(b)).

The NS directional filter brings out E-O oriented structures (lineaments) on the original image; in the same way the directional filter EO, brings out the structures oriented N-S.

The NE-SW directional filter brings out NW-SE oriented structures (lineaments) of the original image; in the same way the NO-SE directional filter, brings out the NE-SW oriented structures. The $7 \times 7$ matrices of these filters are indicated in Table 4.

The lineaments displayed by the processed images will be the subject of a supervised analysis which consists of their direct digitization in the GIS.

For multispectral 1 to 5 combined bands of Landsat-8 $\mathrm{ETM}^{+}$, lineament supervised analysis is performed in filtered images which are displayed in an 

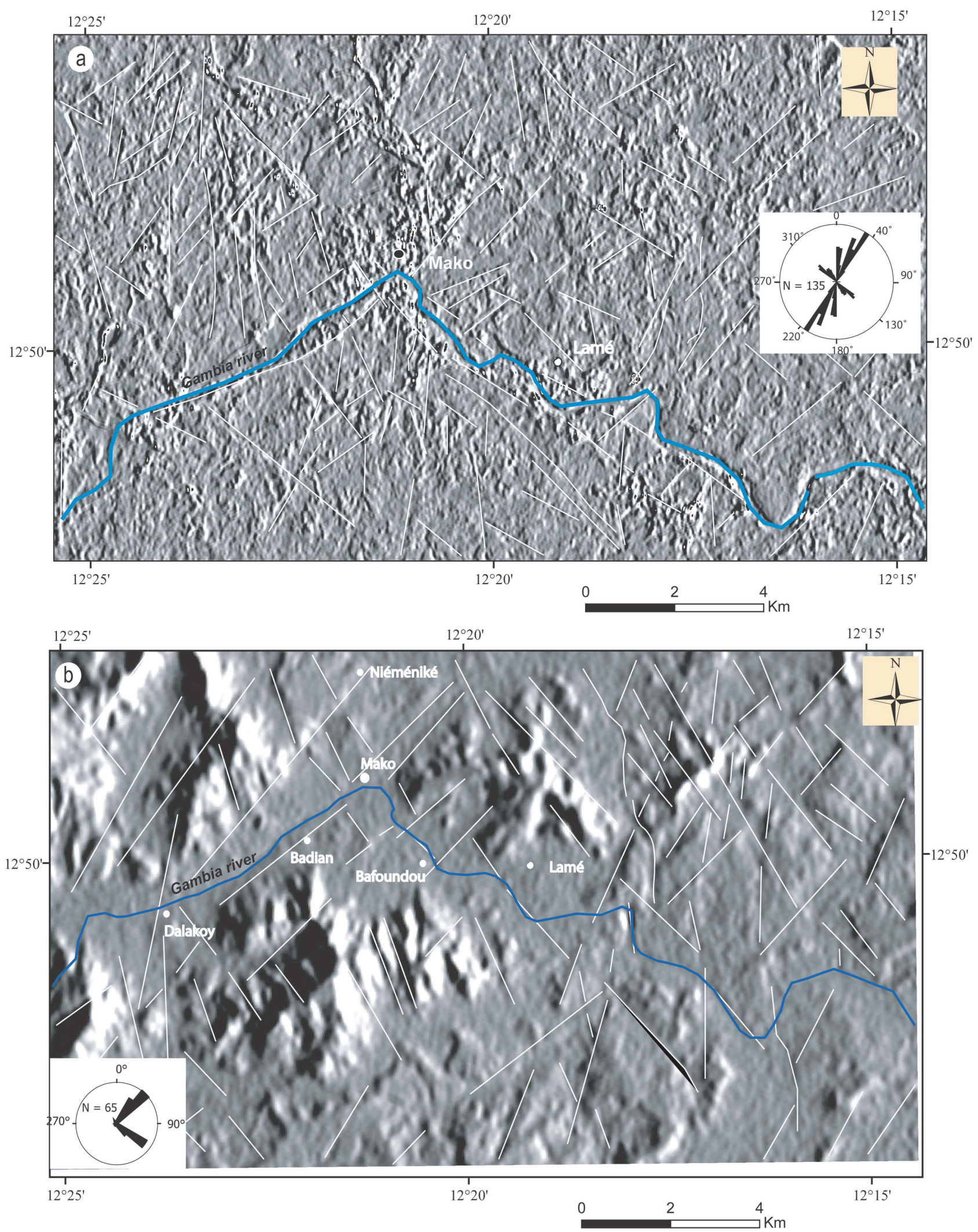

Figure 3. (a) Panchromatic bande of Landsat-8, after directional filtering, showing larges linear structures underlined in white; (b) Shaded and filtering DEM image following the $\mathrm{N} 90^{\circ}$ direction. The different lineaments are underlined in white and their different orientations are summarized in sterographic projection (lower hemisphere) at the bottom of the image. 
Table 3. Matrices of some Sobel directional filters used.

\begin{tabular}{|c|c|c|c|c|c|c|c|c|c|c|c|c|c|}
\hline 1 & 1 & 1 & 2 & 1 & 1 & 1 & -1 & -1 & -1 & 0 & 1 & 1 & 1 \\
\hline 1 & 1 & 2 & 2 & 2 & 1 & 1 & -1 & -1 & -2 & 0 & 2 & 1 & 1 \\
\hline 1 & 2 & 3 & 4 & 3 & 2 & 1 & -1 & -2 & -3 & -0 & 3 & 2 & 1 \\
\hline 0 & 0 & 0 & 0 & 0 & 0 & 0 & -2 & -3 & -4 & 0 & 4 & 3 & 2 \\
\hline-1 & -2 & -3 & -4 & -3 & -2 & -1 & -1 & -2 & -3 & 0 & 3 & 2 & 1 \\
\hline-1 & -1 & -2 & -3 & -2 & -1 & -1 & -1 & -1 & -2 & 0 & 2 & 1 & 1 \\
\hline-1 & -1 & -1 & -2 & -1 & -1 & -1 & -1 & -1 & -1 & 0 & 1 & 1 & 1 \\
\hline \multicolumn{7}{|c|}{ SOBEL Filter N-S } & \multicolumn{7}{|c|}{ SOBEL Filter E-W } \\
\hline 0 & 1 & 1 & 1 & 1 & 1 & 2 & 2 & 1 & 1 & 2 & 1 & 1 & 0 \\
\hline-1 & 0 & 2 & 2 & 2 & 3 & 1 & 1 & 3 & 2 & 2 & 2 & 0 & -1 \\
\hline-1 & -2 & 0 & 3 & 4 & 2 & 1 & 1 & 2 & 4 & 3 & 0 & -2 & -1 \\
\hline-1 & -2 & -3 & 0 & 3 & 2 & 1 & 1 & 2 & 3 & 0 & -3 & -2 & -1 \\
\hline-1 & -2 & -4 & -3 & -0 & 2 & 1 & -1 & -2 & -3 & -4 & -3 & -2 & -1 \\
\hline-1 & -3 & -2 & -2 & -2 & 0 & 1 & -1 & -1 & -2 & -3 & -2 & -1 & -1 \\
\hline-2 & -1 & -1 & -1 & -1 & -1 & 0 & -1 & -1 & -1 & -2 & -1 & -1 & -1 \\
\hline \multicolumn{7}{|c|}{ SOBEL Filter NE-SW } & \multicolumn{7}{|c|}{ SOBEL Filter NW-SE } \\
\hline
\end{tabular}

Table 4. Matrices of some directional filters used.

\begin{tabular}{cccccccccccccc}
\hline-1 & -1 & -1 & 0 & 1 & 1 & 1 & 0 & 1 & 1 & 1 & 1 & 1 & 2 \\
-1 & -1 & -1 & 0 & 1 & 1 & 1 & -1 & 0 & 2 & 2 & 2 & 3 & 1 \\
-1 & -1 & -1 & 0 & 1 & 1 & 1 & -1 & -2 & 0 & 3 & 4 & 2 & 1 \\
-1 & -1 & -1 & 0 & 1 & 1 & 1 & -1 & -2 & -2 & 0 & 3 & 2 & 1 \\
-1 & -1 & -1 & 0 & 1 & -1 & -1 & -1 & -2 & -4 & -3 & 0 & 2 & 1 \\
-1 & -1 & -1 & 0 & 1 & 1 & 1 & -1 & -3 & -2 & -2 & -2 & 0 & 1 \\
-1 & -1 & -1 & 0 & 1 & 1 & 1 & -2 & -1 & -1 & -1 & -1 & -1 & 1
\end{tabular}

Directional Filter N-S

Directional Filter NE-SW

\begin{tabular}{ccccccccccccccc}
\hline 0 & 0 & 0 & -0.7 & -1.41 & -1.41 & -1.41 & -1 & -1 & -1 & -1 & -1 & -1 & -1 \\
0 & 0 & 0 & -0.7 & -1.41 & -1.41 & -1.41 & -1 & -1 & -1 & -1 & -1 & -1 & -1 \\
0 & 0 & 0 & -0.7 & -1.41 & -1.41 & -1.41 & -1 & -1 & -1 & -1 & -1 & -1 & -1 \\
0.71 & 0.71 & 0.71 & 0 & -0.7 & -0.7 & -0.7 & 0 & 0 & 0 & 0 & 0 & 0 & 0 \\
1.41 & 1.41 & 1.41 & 0 & 0 & 0 & 0 & 1 & 1 & 1 & 1 & 1 & 1 & 1 \\
-1 & 1.41 & 1.41 & 0 & 0 & 0 & 0 & 1 & 1 & 1 & 1 & 1 & 1 & 1 \\
-1 & 1.41 & 1.41 & 0 & 0 & 0 & 0 & 1 & 1 & 1 & 1 & 1 & 1 & 1
\end{tabular}

Directional Filter NW-SE

Directional Filter E-W 
appropriate colored composition.

The Red-Green-Blue (RGB) colored compositions processing of 1 to 5 bands of Landsat-8 $\mathrm{ETM}^{+}$, improves the quality of the resulting image to better highlight the geological structures. It is thus possible, from well-defined color combinations, to cancel or minimize the effects of vegetation and clouds on the resulting images, in order to better exhibit the geological structures. In fact, we used in this study the combination in colored composition of 4.3 .2 bands respectively in RGB canals. This combination in colored composition attenuates the effects of clouds and turns vegetation into greyish blue, lateritic soils in yellow and water in blackish blue (Figure 4(a)).

\subsubsection{Geophysical Images}

Geosoft Oasis Montaj mapping software was used for aeromagnetic data processing. The processing performed included transformations and digital filtering techniques, such as pole reduction (RTP) and the first vertical derivative. This treatment improves short-wavelength characteristics and attenuates long-wavelength anomalies associated with deep sources ([29]). This numerical filtering is useful for highlighting shallow structures such as fault and swarm of dykes. The aim of these transformations is to highlight characteristics for structural and geological interpretations ([30] [31] [32] [33]).

Thus, the gray shading electromagnetic image (Figure 4(b)), there clearly appear magnetic discontinuities, which are highlighted geological structures (tectonic structures and lithological boundaries).

The analogical interpretations consisted of lineaments extracting from raster images in form of lineaments map which related to the geological structures.

The geophysical and satellite lineament data will be constrained by field data for a validation of the tectonic structures.

\subsection{Validation of the Tele-Analytical Map}

The validation of the preliminary tele-analytic map is carried out by combination and comparison through a GIS, of structural data from images processing and those identified and located in the field. The final map will take into account the geological data of the pre-existing maps (lithology and tectonic structures). The progress of our approach is presented in Figure 5.

\section{Results}

\subsection{Combination and Analysis of Different Images Data}

The lineaments extracted on the filtered image (panchromatic band 8 of Landsat-8 $\mathrm{ETM}^{+}$and DEM image) in the different filtering directions (NS, EW, NW-SE and NE-SW) are systematically compared to the lineaments obtained on the multispectral images (4.3.2 bands combination of Landsat-8, $\mathrm{ETM}^{+}$) and on geophysical images before being confirmed and digitized. Thus, we will avoid repeating or adding elements that are not likely to be geological lineaments 

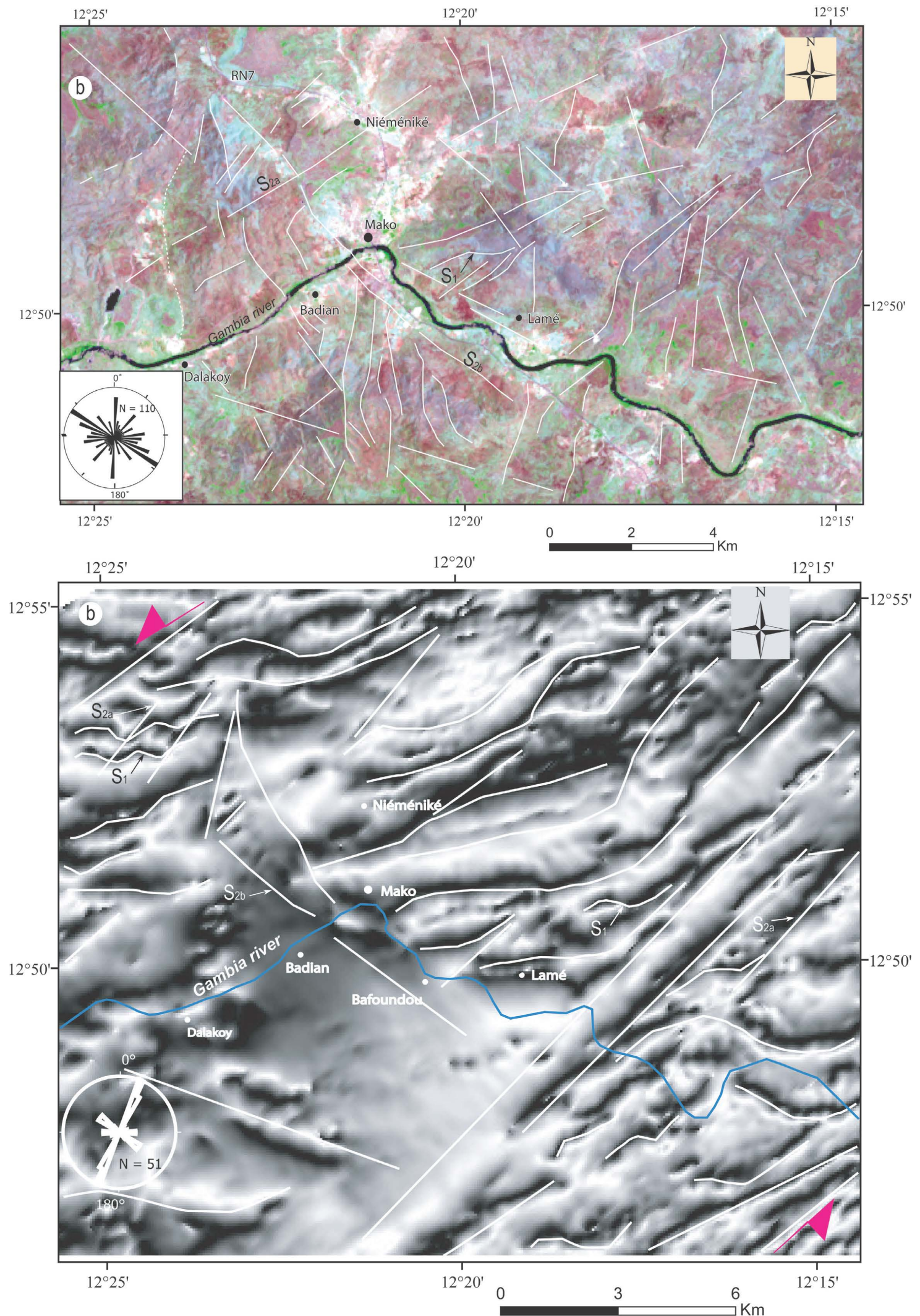

Figure 4. (a) Landsat-8 satellite image (in colored combination) of Mako area showing larges linear structures underlined in white; (b) Aeromagnétic image showing different lineaments, some of which are folded in S or Z shape. 


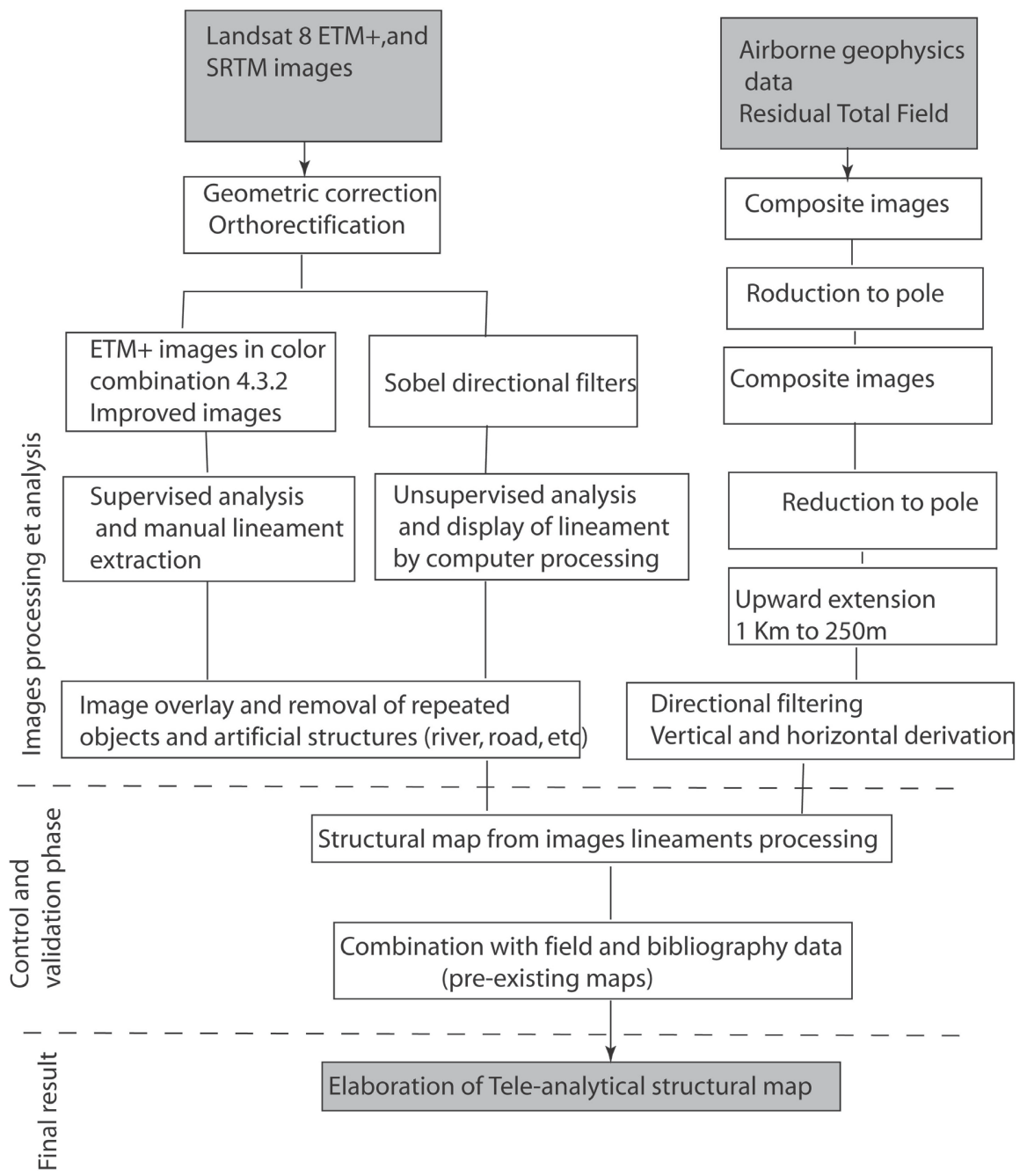

Figure 5. Process of images treatments and analyzes.

(road, wooded boundaries and power lines, etc.). To avoid the segments repetition on this synthesis map, a selective elimination of all the overlapping lineaments is carried out. The tele-analytic map of lineaments from the images processed (Figure 6) is superimposed on the geological map of field data (Figure 7) in order to check the existing correlations and improve the geological map of the area. The stereographic projections of the directional measurements resulting from these different images lineaments are attached as insets to the aforementioned figures. They are compared to that of the field data.

For satellite images, it appears that the linear structures resulting from the enhanced and filtered DEM image are mainly oriented NNE-SSW and NS, with some NW-SE directions and rare EW directions (Figure 3(b)). On the enhanced and filtered panchromatic band (8) images of the Landsat-8, $\mathrm{ETM}^{+}$, the NNE-SSW oriented lineaments remain in the majority (Figure 3(a)). However, NW-SE trending lineaments are more frequent than those NS trending, unlike the results obtained from DEM images. In addition, this Figure 3(a) shows locally folded structures which are arranged in echelon along a potential dextral 

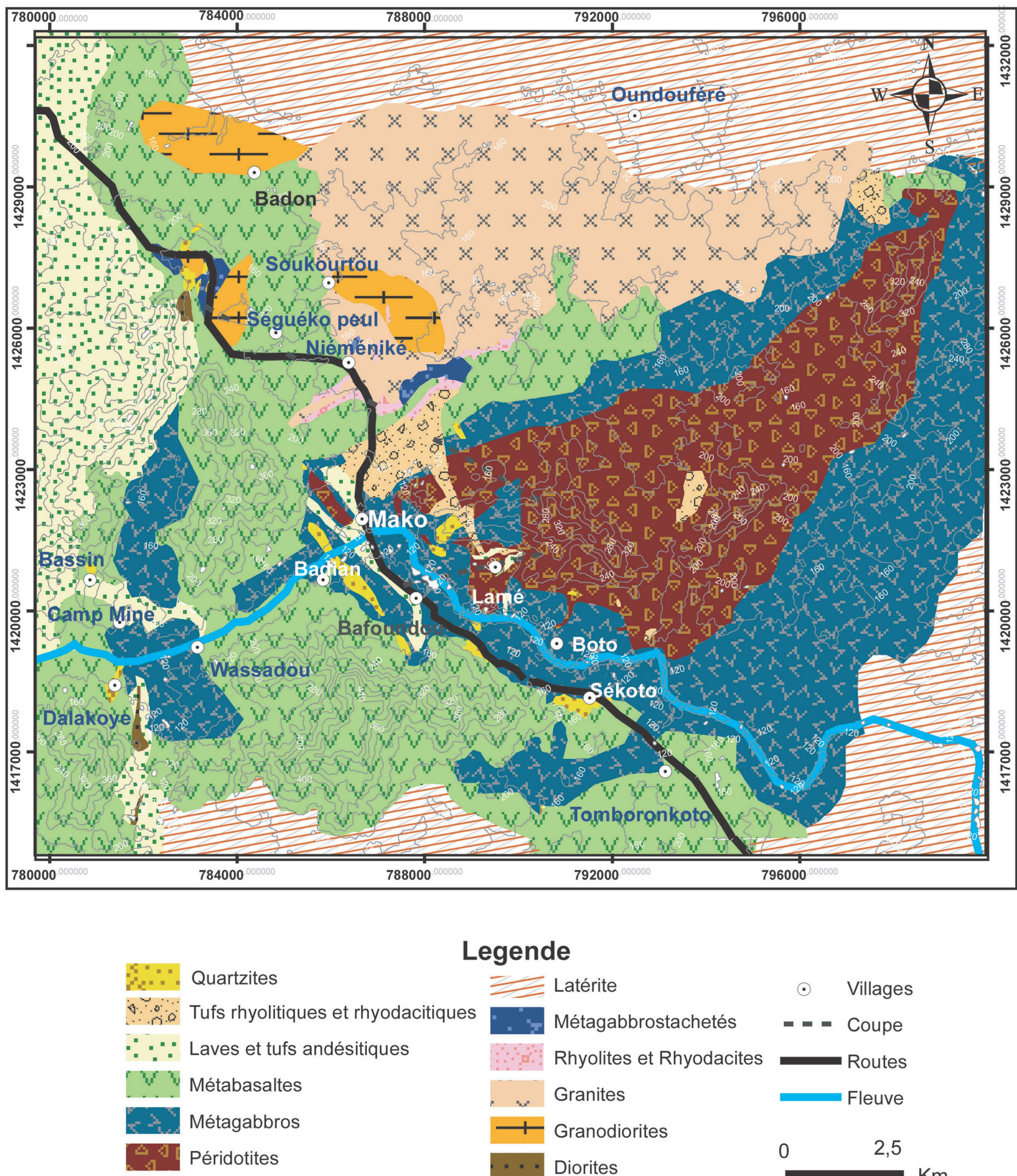

\section{Legende}

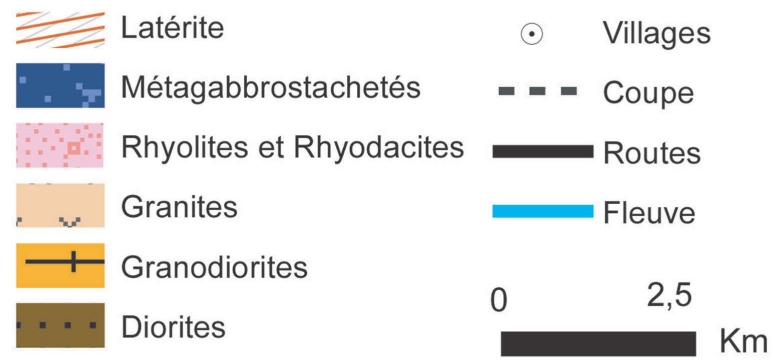

Figure 6. Lithological map of the Mako Paleoproterozoic greenstone belt (modified after [24] [34]). RN7: National road $\mathrm{N}^{\circ} 7$.

shear corridor.

Supervised lineament analysis on multi-spectral 3.4.2 enhanced and color-combined bands of Landsat- $8\left(\mathrm{ETM}^{+}\right)$, corroborates the predominance of the NNE-SSW and NS oriented lineaments (Figure 4). The NW-SE trending 


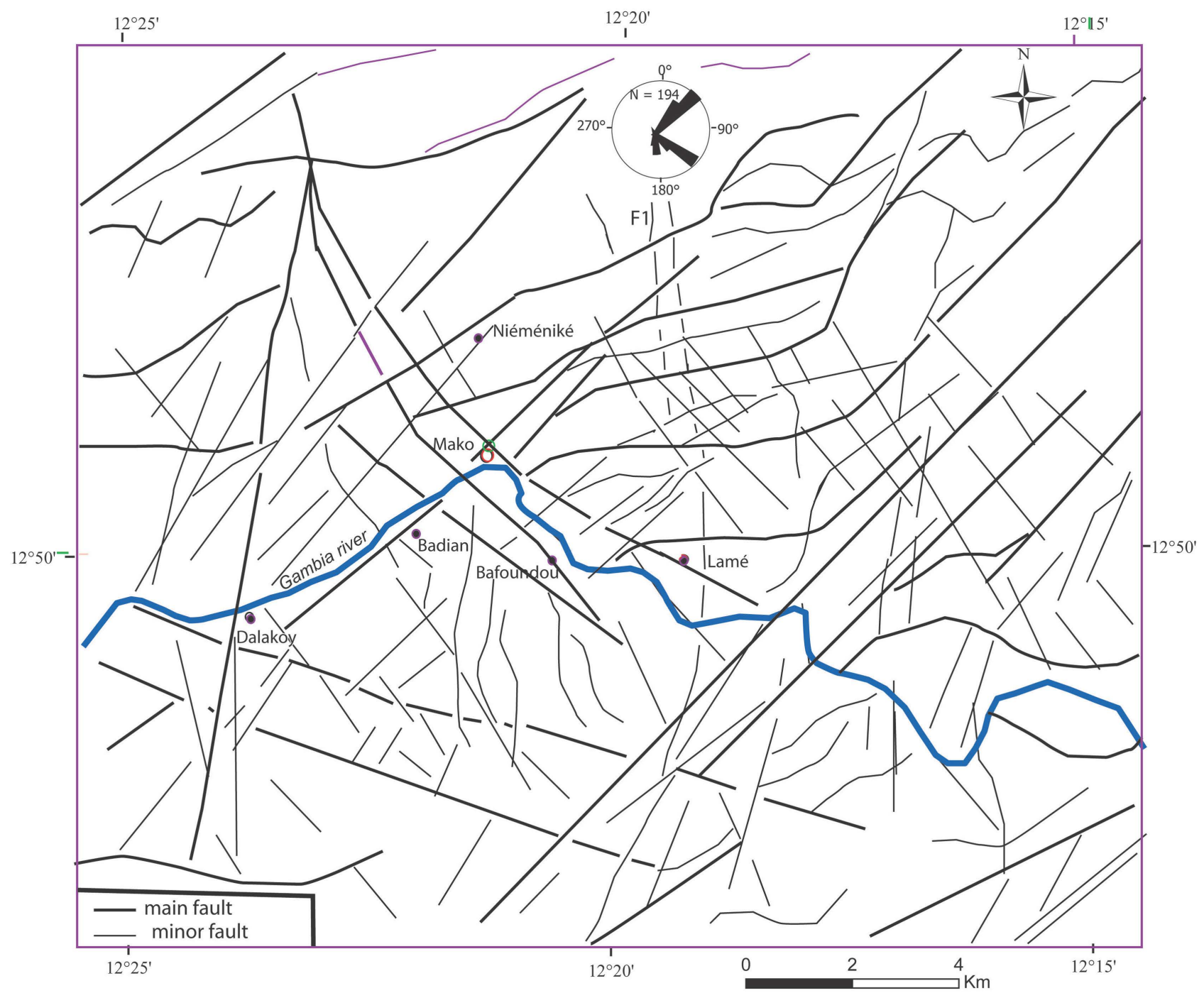

Figure 7. Tele-analytical map of Mako area showing tectonic lineaments which are resulted from satellite and airborne geophysical images analysis.

lineaments, although relatively infrequent, are well distributed throughout the study area and sometimes form large structures which often cross-cut previous lineaments directions. E-W oriented lineaments are rare. We can also note that the trajectory of the large tectonic structures clearly appears on these satellite images. In this case, we can notice that the N-S and NNE-SSE oriented lineaments are sometimes linked to the same linear structure whose trajectory has undergone a great amplitude torsion during the deformation (Figure 4(a)).

For the aeromagnetic geophysical image, the result of the data processing highlights the sub-surface geological structures which appear as multidirectional lineaments associated with elliptical magmatic bodies. The vertical derivate of RTP map, clearly shows the response of the dykes as short wavelength linear anomalies that cross the study area in three main directions: NNE-SSW to NE-SW, N-S, NW-SE and E-W (Figure 4(b)). The comparison with the bibliographic data indicates that dykes are mafic rocks (dolerites) which present a 
post-Birimian age and which are most often intrusive in the Eburnean faults ([1] [11]).

These lineaments are mainly NE-SW oriented, followed by the N-S then NW-SE oriented lineaments. The E-W oriented lineaments are quite rare (Figure 4(b)). In addition, these images show folded or crenulated lineaments, locally arranged in echelons following a sinister potential shear corridor. Indeed, the E-W oriented lineaments are often crenulated by those NE-SW and NW-SE oriented. They would likely be the early structures in the study area. Locally, they are trapped and micro-folded within the NE-SW oriented tectonic corridors (Figure 4(b)).

\subsection{Field Data}

The field data collected in the area are presented in Figure 7. We are represented the mainly structures such as shear zones, fold axis, schistosities, lineations, faults and major fractures.

The schistosities directions recorded in the field are represented on the field data map and projected as roses directional (Figure 7). The $\mathrm{N}^{\circ} 5^{\circ}$ to $\mathrm{N} 100^{\circ}$ oriented $\mathrm{S}_{1}$ schistosity, is the less preserved in the study area. It presents a variable dip direction. It is marked by foliation planes which often intersected or crenulated by posterior schistosities $\left(\mathrm{S}_{2}\right.$ and $\left.\mathrm{S}_{3}\right)$. The $\mathrm{S}_{2}$ schistosity is $\mathrm{N} 00^{\circ}$ to $\mathrm{N} 35^{\circ}\left(\mathrm{S}_{2 \mathrm{a}}\right)$ and $\mathrm{N} 150^{\circ}$ to $\mathrm{N} 160^{\circ}\left(\mathrm{S}_{2 \mathrm{~b}}\right)$ oriented. It constitutes the best preserved structures in the study area. They locally intersect the $S_{1}$ schistosity (Figure 8(a)). In addition, these $S_{2 a}$ and $S_{2 b}$ schistosities are mainly located within major co-directional shear zones and often exhibiting sinister movement ([34]). These are mainly the Lamé (LSZ) and Mako (MSZ) shear zones (Figure 7). The NNESSW and NW-SE $\left(\mathrm{N} 20^{\circ}\right.$ and $\left.\mathrm{N} 130^{\circ}\right)$ oriented $\mathrm{S}_{3}$ schistosity, is weakly recorded in the area. It is often located in minor shear zones which show dextral movement (Figure 8(b)). Folds of variable geometry and size are also identified in the area (Figure 9). These different tectonic structures are associated with three phases of Eburnean deformations $\mathrm{D}_{1}, \mathrm{D}_{2}$ and $\mathrm{D}_{3}([23])$. The Eburnean $\mathrm{D}_{1}$ deformation phase, responsible for the $\mathrm{S}_{1}$ schistosity, is a tangential tectonic which causes thrust towards the $\mathrm{W}$ and the ENE direction ([34]).

The Eburnean $\mathrm{D}_{2}$ deformation phase is a generally sinistral transpression tectonics which causes anastomosed shear zones along the $\mathrm{S}_{2}$ schistosity directions $\left(\mathrm{N} 00^{\circ}\right.$ to $\mathrm{N} 35^{\circ} \mathrm{S}_{2 \mathrm{a}}$, and $\mathrm{N} 150^{\circ}$ to $\mathrm{N} 160^{\circ} \mathrm{S}_{2 \mathrm{~b}}$ ). The Eburnean $\mathrm{D}_{3}$ deformation phase is a dextral transtension which reactivates the structures of the $\mathrm{D}_{2}$ deformation. This $\mathrm{D}_{3}$ Eburnean deformation phase is of low intensity taking into account the others tectonic structures generated in the study area.

\subsection{Analysis and Discussion of the Results}

The lineaments resulting from satellite images (DEM, landsat-8 $8 \mathrm{ETM}^{+}$) and aeromagnetic geophysics as well as field data (schistosities, faults and shear zones), present similar orientations (Figure 3, Figure 4 and Figure 6). 

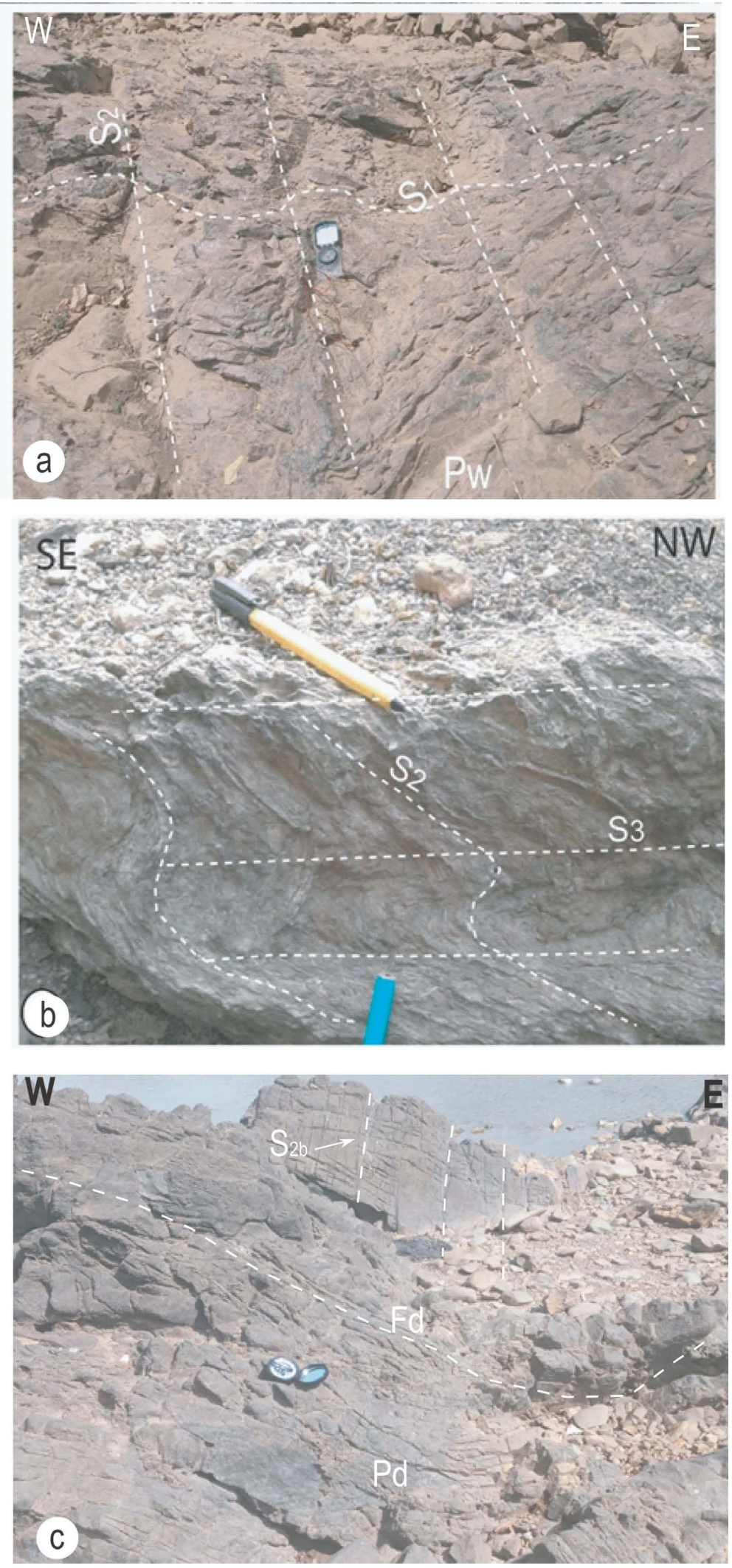

Figure 8. (a) $\mathrm{N} 160^{\circ}$ oriented $\mathrm{S}_{2}$ schistosity which cross-cut and crenulate the $\mathrm{N} 45^{\circ}$ oriented S1 schistosity within pillowed metabasalts (Pw); (b) S3 schistosity in rhyolitic tufs of Mako; (c) Folds in Mako metaperidotite rocks. 

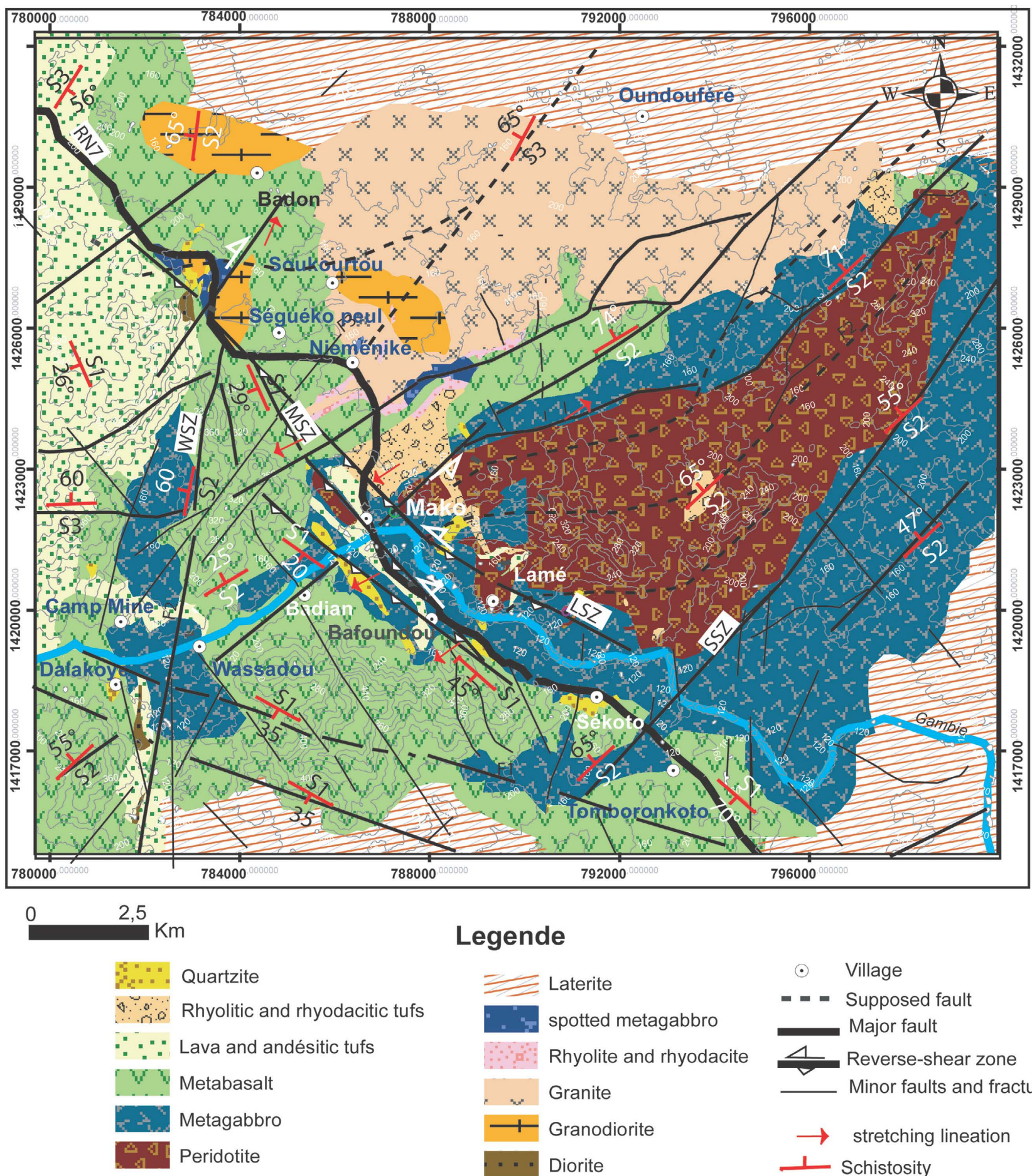

\section{Legende}

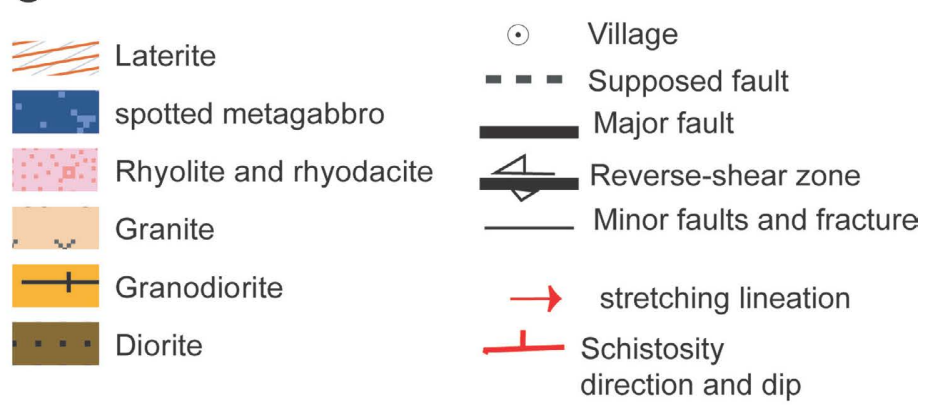

Figure 9. Geological map of Mako area resulting from combinaison of lithologcal data and tele-analytical tectonic structures from images treatments.

On these different images, NE-SW oriented lineaments are more frequent followed by those NS oriented, then NW-SE oriented lineaments. E-W oriented lineaments are quite rare and appear particularly on the aeromagnetic image. In the landsat- $8 \mathrm{ETM}^{+}$(colored composition) and aeromagnetic geophysical im- 
ages, curvilinear, folded and crenulated lineaments appear (Figure 3(b), Figure 4(a)). The distribution and the relative importance of the different direction families of lineament can be interpreted in comparison with the results of field data and previous work ([2] [3] [23] [34]).

The $\mathrm{N} 75^{\circ}$ to $\mathrm{N} 100^{\circ}$ oriented $\mathrm{S}_{1}$ schistosity, is poorly preserved in the field and often intersected or crenulated by late schistosities $\left(\mathrm{S}_{2}\right.$ and $\left.\mathrm{S}_{3}\right)$. It would correspond to the E-W oriented lineaments which are also infrequent on the studied images (Figure 3 and Figure 4). In addition, these E-W oriented lineaments show on Landsat- $8 \mathrm{ETM}^{+}$(colored composition) and aeromagnetic geophysical images the wrench and wrinkle deformations relative to the NE-SW and NW-SE oriented lineaments which are associated with the late deformations $\left(\mathrm{D}_{2}\right.$ and $\left.\mathrm{D}_{3}\right)$.

The NS to NE-SW and NW-SE oriented lineaments are coincide with the direction of the $S_{2}$ schistosities, in particular $S_{2 a}$ (NS to NE-SW oriented) and $S_{2 b}$ (NW-SE oriented) and the large meridian to sub-meridian thrust or reverseshear zones which are identified in the study sector (Figure 7). These Eburnean $\mathrm{D}_{2}$ structures of the deformation intersect and create the crenulation of the $\mathrm{S}_{1}$ schistosity ( $\mathrm{N} 75^{\circ}$ to $\mathrm{N} 100^{\circ}$ oriented) and associated thrust zones ([34]).

The NNE-SSW and NW-SE oriented $\mathrm{S}_{3}$ schistosity which is weakly recorded in the field, is not clearly identified on the images and remains confused with the structures of the $\mathrm{D}_{2}$ deformation. (Figure $8(\mathrm{~b})$ ). However, it would be correlated with a part of the NNE-SSW and NW-SE oriented lineaments.

These lineaments from different images would be relative to geological structures associated with Eburnean and post-Eburnean tectonic events in the Mako area. Their structural and geometric relationship support a polyphase Eburnean deformation. Most of the NS and NNE-SSW oriented lineaments, and part of the NW-SE oriented lineaments would be related to the $\mathrm{D}_{2}$ major Eburnean deformation phase. These lineaments are correlated with the $S_{2}$ schistosity of the $D_{2}$ Eburnean deformation phase and essentially correspond to shear zones, faults and fold axis. Most of these $\mathrm{D}_{2}$ tectonic structures show sinistral movement. Thus, the trajectory of Mako Shear Zone (MSZ) which represents one of the major tectonic structures of the area has been clearly specified. The E-W oriented lineaments predate the $\mathrm{D}_{2}$ Eburnean deformation phase, because they are cross-cut, crenulated or sheared by these former. Indeed, these E-W lineaments would be relative to the Eburnean $\mathrm{D}_{1}$ deformation phase characterized by thrusting towards the W and the ENE ([34]). Some NNE-SSW and NW-SE oriented lineaments intersect or shift the $\mathrm{D}_{2}$ Eburnean deformation structures and would therefore be posterior. These structures would be relative to a late $\mathrm{D}_{3}$ Eburnean phase or even post Eburnean deformation ([23]).

\section{Conclusions}

The study of satellite and geophysical images lineaments, combined with field data, allow us to establish a new structural map of the Mako area (Figure 9). 
Four directions of lineament (NS, NE-SW, NW-SE, and EW oriented) with varying importance, were identified and mapped in the Mako area. The lineaments resulting from satellite (DEM and Landsat- $8 \mathrm{ETM}^{+}$) as well as aeromagnetic geophysics images, present almost similar orientations in the studied area (Figure 3 and Figure 4). Through these different images, NE-SW oriented lineaments are more frequent followed by those NS oriented, then NW-SE oriented lineaments. EW-oriented lineaments are quite rare and appear particularly on the aeromagnetic geophysical image. Folded, wrench and wrinkle lineaments are also mapped on 4-3-2 colored composition bands of Landsat-8 $\mathrm{EMT}^{+}$and airborne geophysical images (Figure 4(a) and Figure 4(b)).

These lineaments from different images would be relatives to tectonic structures of Eburnean and post-Eburnean orogeny's events which are affected the Birimian and Neoproterozoic formations of the Mako area.

\section{Conflicts of Interest}

The authors declare no conflicts of interest regarding the publication of this paper.

\section{References}

[1] Bassot, J.P. (1966) Etude géologique du Sénégal oriental et de ses confins GuinéoMaliens. Mémoire. B.R.G.M. $\mathrm{N}^{\circ}$ 40, 332 p.

[2] Ledru, P., Pons, J.P., Milési, J.P., Dommanget, A., Johan, V., Diallo, M. and Vinchon, C. (1989) Tectonique transcurrente et évolution polycyclique dans le Birimien, protérozoique inférieur du Sénégal-Mali (Afrique de l'Ouest). Comptes Rendus de 1 Académie des Sciences, 308, 117-122.

[3] Pons, J., Oudin, C. and Valéro, J. (1992) Kinematics of Large Syn-Orogenic Intrusions: Example of the Lower Proterozoic Saraya Batholith (Eastern Senegal). Geologische Rundschau, 82, 473-486. https://doi.org/10.1007/BF01828610

[4] Dabo, M. and Aifa, T. (2010) Structural Styles and Tectonic Evolution of the Kolia-Boboti Sedimentary Basin, Kédougou-Kéniéba Inlier, Eastern Senegal. Comptes Rendus Geoscience, 342, 796-805. https://doi.org/10.1016/j.crte.2010.06.002

[5] O'Leary, D.W., Frieddman, J.D. and Pohn, H.A. (1976) Lineament, Linear, Lineation: Some Porposed New Standards for Old Terms. Geological Society of America Bulletin, 87, 1463-1469. https://doi.org/10.1130/0016-7606(1976)87<1463:LLLSPN>2.0.CO;2

[6] Yatabe, S. and Howarth, P.H. (1984) Lineament Enhancement and Interpretation in Northern Ontario from Airborne, Multispectral Scanner Data. Proceedings of the International Symposium on Remote Sensing, 3D Thematic Conference, Remote Sensing for Exploration Geology, Washington, 12 April 1984, 1-8.

[7] Soesilo, I. and Hoppin, R.A. (1986) Evaluation of Digitally Processed Landsat Imagery and SIR-A Imagery for Geological Analysis of West Java Region, Indonesia. Symposium on Remote Sensing for Resources Development and Environmental Management, Nederland, 25 August 1986, 173-182.

[8] Pouliot, G. (1986) Intégration de données satellites dans l'évaluation de cible de prospection minière dans la bande volcano-sédimentaire Ascoot-Weedom, cantons de l'est, Québec. Mémoire de maîtrise, Département de Géologie, Université de 
Sherbrooke, $64 \mathrm{p}$.

[9] Deslandes, S. (1990) Initiation aux méthodes de traitement numérique des images satellites, sur le système PCI Inc., EASUPACE. CARTEL, 32 p.

[10] Bassot, J.P. (1997) Albitisations dans le Paléoprotérozoïque de l’Est sénégal: Relations avec les minéralisations ferriféres de la rive gauche de la Falémé. Revue des Sciences de la Terre Africaines, 25, 353-367. https://doi.org/10.1016/S0899-5362(97)00109-7

[11] Théveniaut, H., Ndiaye, P.M., Buscail, F., Couëffé, R., Delor, C., Fullgraf, T. and Goujou, J.C. (2010) Notice explicative de la carte géologique du Sénégal oriental à 1/500 000. Ministère des Mines, de l'Industrie, de l'Agro-Industrie et des PME, Direction des Mines et de la Géologie, Dakar, $120 \mathrm{p}$.

[12] Ledru, P., Pons, J., Milési, J.P., Feybesse, J.L. and Johan, V. (1991) Transcurrent Tectonics and Polycyclic Evolution in the Lower Proterozoic of Senegal-Mali. Precambrian Research, 50, 337-354. https://doi.org/10.1016/0301-9268(91)90028-9

[13] Bassot, J.P. and Caen-Vachette, M. (1984) Données géochronologiques et géochimiques nouvelles sur les granitoïdes de l'Est Sénégal: implication sur l'histoire géologique du Birrimien de cette région. In: Klerkx, J. and Michot, J., Eds., Géol. Afric. Tervuren, 1991-209.

[14] Boher, M., Abouchami, W., Michard, A., Albarède, F. and Arndt, N.T. (1992) Crustal growth in West Africa at 2.1 Ga. Journal of Geophysical Research, 97, 345-369. https://doi.org/10.1029/91JB01640

[15] Dia, A., Van Schmus, W.R. and Kröner, A. (1997) Isotopic Constraints on the Age and Formation of a Palaeoproterozoic Volcanic Arc Complex in the Kedougou Inlier, Eastern Senegal, West Africa. Journal of African Earth Sciences, 24, 197-213. https://doi.org/10.1016/S0899-5362(97)00038-9

[16] Gueye, M., Siegesmund, S., Wemmer, K., Pawlig, S., Drobe, M., Nolte, N. and Layer, P. (2007) New Evidences for an Early Birimian Evolution in the West African Craton: An Example from the Kédougou-Kénieba Inlier, Southeast Sénégal. South African Journal of Geology, 110, 511-534. https://doi.org/10.2113/gssajg.110.4.511

[17] Bassot, J.P. (1987) Le complexe volcano-plutonique calco-alcalin de la rivière Daléma (Est Sénégal): Discussion de sa signification géodynamique dans le cadre de l'orogénie éburnéenne (Protérozoïque inférieur). Journal of African Earth Sciences, 6, 109-115. https://doi.org/10.1016/0899-5362(87)90091-1

[18] Hirdes, W. and Davis, D.W. (2002) U/Pb Geochronology of Paleoproterozoic Rocks in the Southern Part of the Kedougou-Kéniéba Inlier, Senegal, West Africa: Evidence for Diachronous Accretionary Development of the Eburnean Province. Precambrian Research, 118, 83-99. https://doi.org/10.1016/S0301-9268(02)00080-3

[19] Calvez, J.Y., Feybesse, J.L., Ledru, P. and Milési, J.P. (1990) Géochronologie du Protérozoïque inférieur du Craton Ouest africain (méthode d'évaporation directe de zircons isolés). $13^{\text {ème }}$ R.S.T., Grenoble, Abstr., 26 p.

[20] Milési, J.P., Feybesse, J.L., Ledru, P., Dommanget, A., Quedraogo, M.F., Marcoux, E., Prost, A., Vinchon, C., Sylvain, J.P., Johan, V., Tegyey, M., Calvez, J.Y. and Lagny, P. (1989) Les minéralisations aurifères de l'Afrique de l'Ouest. Leurs relations avec l'évolution lithostructurale au Protérozoïque inférieur. Chronique Recherche Minière, 497, 3-98.

[21] Bassot, J.P., Cantagrel, J.M. and Jamond, C. (1986) Les nouvelles données géochronologiques sur les dolérites et gabbros de l'Est Sénégal et de la Guinée Bissau: Réflexion sur l'âge de la mise en place et la répartition du magmatisme tholéitique “continental” à l'échelle de l'Afrique de l'Ouest. In Garcia de Orta, Série de Geolo- 
gia, 9, 1-14.

[22] Dia, A. (1988) Caractère et signification des complexes magmatiques et métamorphiques du secteur de Sandikounda-Laminia (Nord de la boutonnière de Kédougou, Est du Sénégal): Un modèle géodynamique du Birimien de l'Afrique de l'Ouest. Thèse Université Dakar, Sénégal, 350 p.

[23] Dabo, M., Aïfa, T., Nging, I., Faye, M., Ba, M.F. and Ngom, P.M. (2017) Lithological Architecture and Petrography of the Mako Birimian Greenstone Belt, Kedougou-Kenieba Inlier, Eastern Senegal. Journal of African Earth Sciences, 131, 128-144. https://doi.org/10.1016/j.jafrearsci.2017.04.005

[24] Dabo, M., Gassama, T.A.I. and Ngom, P.M. (2018) Thrust to Transpression and Transtension Tectonics during the Paleoproterozoic Evolution of the Birimian Greenstone Belt of Mako, Kédougou-Kéniéba Inlier, Eastern Senegal. Journal of African Earth Sciences, 148, 14-29. https://doi.org/10.1016/j.jafrearsci.2018.05.010

[25] Gillespie, A.R. (1976) Directional Fabric Introduced by Digital Filtring of Image. Proceedings of the Second International Conference on Tectonics, Delaware, 17 February 1972, 500-507.

[26] Seidman, J.B. (1972) Some Practical Applications of Digital Filtering in Image Processing: Proceedings in Image Processing. Proceedings of the Computer Image and Recognition Symposium, Columbia, 9.1.1-9.1.12.

[27] Deslandes, S. and Gwyn, Q.H.J. (1991) Evaluation de SPOT et SESAT pour la cartographie des linéments: Comparaison basée sur l'analyse de spectres de Fourie. Journal canadien de télédétection, 17, 98-110. https://doi.org/10.1080/07038992.1991.10855284

[28] Saint-Jean, R. (1992) Analyse structurale et lithologique d'une image radar en bande C. région de l'Inlet de Bathurst, T.N.O. (Nunavut), Canada. Mémoire de maîtrise, Département de géologie, Université de Sherbrooke, 109 p.

[29] Reeves, C.V. (2005) Aeromagnetic Surveys Principles, Practice and Interpretation. Terrassement, Washington DC, $155 \mathrm{p}$.

[30] Airo, M.L. and Wennerström, M. (2010) Application of Regional Aeromagnetic Data in Targeting Detailed Fracture Zones. Journal of Applied Geophysics, 71, 62-70. https://doi.org/10.1016/j.jappgeo.2010.03.003

[31] Nasuti, A., Roberts, D. and Gernigon, L. (2015) Multiphase Mafic Dykes in the Caledonides of Northern Finnmark Revealed by a New High-Resolution Aeromagnetic Dataset. Norwegian Journal of Geology, 95, 1-13.

https://doi.org/10.17850/njg95-3-02

[32] Maacha, L., Jaffal, M., Jarni, A., Kchikach, A., Mouguina, E.M., Zouhair, M. and Ennaciri, A. (2017) Une contribution des données magnétiques aéroportées et de la spectrométrie gamma dans la compréhension de la structure du massif hercynien central du jebilet et ses implications pour l'exploitation minière. Revue des Sciences de la Terre Africaines, 134, 389-403. https://doi.org/10.1016/j.jafrearsci.2017.07.012

[33] Brethes, A., Guarnieri, P., Rasmussen, T.M. and Bauer, T.E. (2018) Interpretation of Aeromagnetic Data in the Jameson Land Basin, Central East Greenland: Structures and Related Mineralized Systems. Tectonophysics, 724-725, 116-136.

https://doi.org/10.1016/j.tecto.2018.01.008

[34] Gassama, I. (2021) Évolution lithostructurale des formations birimiennes du secteur de mako (boutonniere de kedougou-kenieba, Senegal). Thèse de Doctorat unique Univ. Cheikh Anta Diop de Dakar, Dakar, 175 p. 